\title{
RELATIONSHIP OF SERUM FASTING INSULIN WITH GONADOTROPINS IN INFERTILE WOMEN
}

\author{
SHAMIMA BARI ${ }^{1}$, ROKEYA BEGUM ${ }^{2}$, QAZI SHAMIMA AKTER ${ }^{3}$, TANVIR ALAM ${ }^{4}$, KADEJA BEGUM ${ }^{5}$ \\ ${ }^{1}$ Assistant Professor, Department of Physiology, Ibrahim Medical College, Dhaka. \\ ${ }^{2}$ Former Professor and Head, Department of Physiology, Dhaka Medical College, Dhaka. \\ ${ }^{3}$ Professor and Head, Department of Physiology, Dhaka Medical College, Dhaka. \\ ${ }^{4}$ Assistant Professor, Department of Physiology, Holly family Medical College, Dhaka. \\ ${ }^{5}$ Assistant Professor, Department of Physiology, Holly family Medical College, Dhaka.
}

\begin{abstract}
Background: Infertility has become a global health problem in the world wide affecting 8-10\% of couple. It is also a matter of social injustice and inequality. Increase level of insulin has been implicated as a cause of infertility. Objective: To find out the association of fasting serum insulin level with gonadotropins in infertile women. Methods: This cross sectional study was conducted in the department of Physiology, Dhaka Medical College, Dhaka from July 2010 to June 2011. A total number of 150 female age ranged from 20 - 40 years were included in this study. Out of them100 infertile women were selected as study group (group B). Group B was subdivided into group $B_{1}$ and $B_{2}$. Group $B_{1}$ consisted of 50 primary infertile women and group $B_{2}$ consisted of 50 secondary infertile women. Rest 50 age matched apparently healthy parous women were considered as base line control group $A$. All the study subjects were selected from out patient department of infertility unit, BSMMU, Dhaka. The control subjects were selected by personal contact. Serum fasting insulin was measured by enzyme-link-immunosorbend assay. Fasting blood glucose and blood glucose two hours after breakfast were measured by glucose oxidase method. The Data were collected in a prescribed data sheet after taking written consent. Statistical analyses were done by unpaired students " $t$ " tests by SPSS program version 12. The level of significance was calculated and $p$ value $<0.05$ was accepted as level of significance. Results: In this study, the mean fasting serum insulin level were significantly higher in infertile women than those of fertile women $(p<0.001)$. Within the study group serum fasting insulin was higher in primary infertile women than that of secondary infertile women both were statistically not significant. Again, serum FSH and LH levels were significantly lower $(P<.0001)$ in infertile women than those of fertile women. But serum FSH level was lower and $\mathrm{LH}$ level was higher in primary infertile women than that of secondary infertile women. In addition, fasting blood glucose level was almost similar but within normal limits in all groups. Blood glucose $2 \mathrm{HABF}$ was significantly higher in secondary infertile women than that of fertile women but within in normal limit. Moreover, fasting serum insulin level was negatively correlated with serum FSH and LH in primary infertility but negatively correlated with serum FSH and positive correlation with serum $\mathrm{LH}$ in secondary infertility. Conclusion: From the above study it may be concluded that fasting serum insulin level was higher in infertile women than those of healthy fertile women. These alterations may lead to menstrual irregularities, ovulatory dysfunction and infertility.
\end{abstract}

Keywords: Infertility, Insulin, FSH, LH.

(Bangladesh J Physiol Pharmacol 2013;29(1\&2):17-24)

\section{INTRODUCTION}

Infertility is defined as the inability of couple to conceive after 1 years of frequent unprotected intercourse without contraception. ${ }^{1,2}$ Infertility has become a global health problem of twenty first century affecting approximately $8-10 \%$ of couple worldwide. The main causes of sub fertility can be due to ovarian

Address for correspondence: Shamima Bari, Assistant Professor, Department of Physiology, Ibrahim Medical College, Dhaka. E-mail: shamima.bari@yahoo.com factor (30-40\%), cervical factor (5\%), male factor (25$40 \%)$ and unexplained cause $(10-15 \%){ }^{3}$ Primary infertility denotes those women who have never conceived. Secondary infertility indicates; conceive previously but failure to conceive subsequently. ${ }^{4}$

A global review of infertility from the world Fertility Survey estimated rates of infertility both primary and secondary approximately $10 \%$ in South Asia, $8 \%$ in India, $10 \%$ in Pakistan, $11 \%$ in Sri Lanka, $12 \%$ in Nepal and $15 \%$ in Bangladesh. ${ }^{5}$ 
High level of insulin can be as a metabolic state where normal glucose homeostasis mechanisms fail to operate properly. The American Diabetes Association has characterized hyperinsulinemia or insulin resistance is a state of impaired metabolic response to insulin. ${ }^{6}$ To achieve euglycemia, the pancreas over secretes insulin. ${ }^{7}$ High level of insulin in infertile women are the risk for metabolic syndrome and coronary artery disease and also lead to an increase risk of miscarriage ,pre- mature birth and birth defects. ${ }^{8}$

Again, increase level of insulin may cause hormonal imbalance in the pituitary gland and ovary. This leads to an increased secretion of lutenizing hormone (LH). Increased $\mathrm{LH}$ secretion then causes ovulation disorders, menstrual irregularities and infertility. ${ }^{9,10}$

High level of insulin may be due to reduced number of insulin receptors, insulin resistance, and altered the insulin to receptor interaction or post receptor failure. In infertile women, post receptor defect is the main cause of hyperinsulinemia. High level of insulin may causes hyperandrogenemia and also conversion of androstenedione to estrone. Increase level of estrone level may causes increased prolactin level in $30 \%-40 \%$ patients 3 .

Many investigators of different countries reported that high level of insulin may cause increase secretion of androgens (male hormones) in the female which worsen the symptom of infertility. In addition, hyperinsulinemia produces the hyperandrogenism by increasing ovarian androgen production, particularly testosterone and by decreasing the sex hormone binding globulin concentration. . $^{11,12,13}$ The high level of androgenic hormones interfere with the pituitary ovarian axis, leading to increased LH levels, anovulation, amenorrhea, recurrent pregnancy loss, and infertility. 14,15,16,17.

Again, increased level of insulin may causes abnormal glucose uptake, impaired glucose tolarence abnormal glucose metabolism and increase basal hepatic glucose production that may lead to increase blood level in infertile women.

Therefore, the present study has been undertaken to measure fasting serum insulin level to evaluate the relationship of gonadotropins ( $\mathrm{FSH}, \mathrm{LH})$ in infertile women. Hence assessment of serum fasting insulin level are mandatory in all infertile women.

\section{METHODOLOGY}

This cross sectional study was carried out in the department of Physiology, Dhaka Medical College, Dhaka from July 2010 to June 2011 and the protocol was approved by Ethical Review Committee of Dhaka Medical College, Dhaka. Female with tubal factor, congenital anomaly of urogenital tract and any obvious organic lesion or pelvic inflammatory diseases, lactating women were excluded from the study. A total number of 150 female age ranged from 20-40 years were included in this study. Out of them 100 infertile women were selected as study group (group B) and study subjects were selected from out patient department of infertility unit, BSMMU, Dhaka. Group B was subdivided into group $B_{1}$ and $B_{2}$. Group $B_{1}$ consisted of 50 primary infertile women and group $B_{2}$ consisted of 50 secondary infertile women. Rest 50 age matched apparently healthy parous women were considered as base line control group and were selected by personal contact. After selection of the subject the purpose and benefits of the study were explained to each subject and informed written consent was taken from them. A detailed personal, medical, family, socio-economic and drug history were recorded in a prefixed questionnaire foam. Blood were collected from subjecte in $2^{\text {nd }}$ day of menstrual cycle. With all aseptic precaution, five (5) $\mathrm{ml}$ of venous blood was drown from medialcubital vien by disposable plastic syringe. Blood was allowed to clot and then centrifuged at a rate of $3000 \mathrm{rpm}$ for 5-10 minutes and supernatant clear serum was separated and preserved at $-28^{\circ} \mathrm{C}$ for estimation of serum insulin, FBG, blood glucose $2 \mathrm{HABF}$, serum FSH and LH. Serum $\mathrm{FSH}$ and $\mathrm{LH}$ were measured by radioimmunoassay at the laboratory of centre for Nuclear Medicine and Ultrasound, Dhaka Medical College, Dhaka. Fasting serum insulin was measured by ELISA method, fasting blood glucose and blood glucose $2 \mathrm{HABF}$ were measured by glucose oxidase method at the laboratory of endocrinology, BIRDEM. Statistical done analysis was done by using statistical package of social service (SPSS) version12. The results were expressed as mean $( \pm S D)$. Comparison between two groups were done by using unpaired Students' tests and correlation analysis was done by using Pearson's correlation analysis. The test of significant was calculated and $p$ value $<0.05$ was accepted as level of significance.

\section{RESULTS}

Anthropometric data of study subjects are presented in Table I. In this study, mean ( \pm SD) age in different groups were almost similar and no statistically significant differences were observed between the study groups and control group. So the ages were well matched for the study. The mean $(\underline{+} S D)$ BMI were significantly higher $(p<0.001)$ in group $B_{1}$ and $B_{2}$ in compression to those of group $A$. Wherease, there was no significant differences of this value was observed between group $B_{1}$ vs $B_{2}$. (Table $I$ ) 
Table-I

Age and body Mass Index (BMI) in different groups

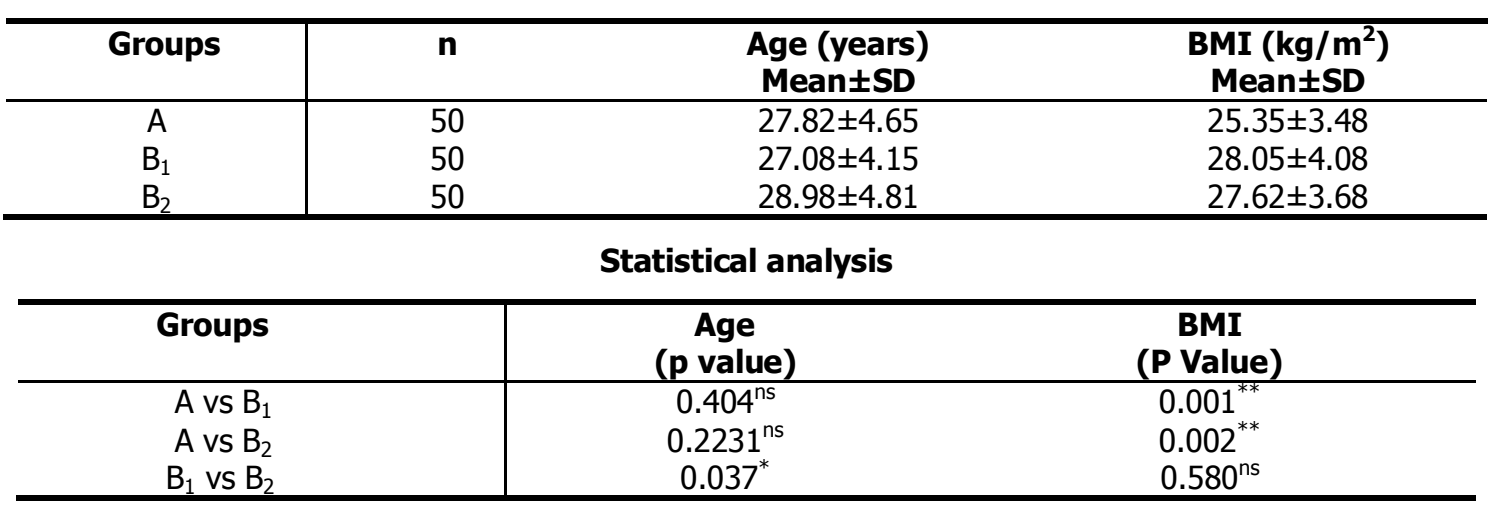

The results are expressed as Mean \pm SD. Unpaired Student's ' $t$ ' test was performed to compare between groups. The test of significance was calculated and $p$ values $<0.05$ was accepted as level of significance.
Group A
Group $B_{1}$ :
$\begin{array}{ll}\text { : Fertile women } & \mathrm{n} \\ \text { Primary infertility df } & = \\ \text { Secondary infertility ns } & =\end{array}$
Group $B_{2}$ :
$=\quad$ Number of subjects
Degree of freedom
Not significant
* $=\quad$ Significant at $\mathrm{P}<0.05$

The mean ( $( \pm S D)$ fasting serum insulin levels were $17.37 \pm 3.05,20.04 \pm 3.46$ and $19.13 \pm 2.62 \mu \mathrm{IU} / \mathrm{ml}$ in groups $A_{\text {, }}$ $B_{1}$ and $B_{2}$ respectively. In this study, mean $( \pm S D)$ fasting serum insulin levels were higher in group $B_{1}$ and $B_{2}$ in comparison to that of group $A$ which were statistically highly significant $(P<0.0001)$. Again, the fasting serum insulin was higher in group $B_{1}$ than that of group $B_{2}$ but the difference was not statistically significant.( Table-II )

\section{Table-II}

Serum insulin levels in different groups

\begin{tabular}{c|cl}
\hline Groups & $\mathbf{n}$ & $\begin{array}{l}\text { Serum insulin } \\
(\boldsymbol{\mu I U} / \mathbf{m l}) \text { Mean } \pm \text { SD }\end{array}$ \\
\hline$A$ & 50 & $17.37 \pm 3.05$ \\
$B_{1}$ & 50 & $20.04 \pm 3.46$ \\
$B_{2}$ & 50 & $19.13 \pm 2.62$ \\
\hline
\end{tabular}

Statistical analysis

\begin{tabular}{c|cc}
\hline Groups & (p value) & $\begin{array}{c}\text { Serum Insuline } \\
\text { (P Value) }\end{array}$ \\
\hline$A$ vs B 1 & $0.007^{* *}$ & $0.0001^{* * *}$ \\
$A$ vs $B_{2}$ & $0.0001^{* * *}$ & $0.003^{* *}$ \\
$B_{1}$ vs B & $0.599^{\text {ns }}$ & $0.140^{\text {ns }}$ \\
\hline
\end{tabular}

The results are expressed as Mean \pm SD. Unpaired Student's't' test was performed to compare between groups. The test of significance was calculated and $p$ values $<0.05$ was accepted as level of significance.

\begin{tabular}{|c|c|c|c|c|}
\hline $\begin{array}{l}\text { Group A } \\
\text { Group B } \\
\text { Group } B_{2}\end{array}$ & $\begin{array}{l}\text { : Fertile women } \\
\text { : Primary infertility } \\
\text { : Secondary infertility }\end{array}$ & $\begin{array}{l}\mathrm{n} \\
\mathrm{df} \\
\mathrm{ns}\end{array}$ & $\begin{array}{l}= \\
= \\
=\end{array}$ & $\begin{array}{l}\text { Number of subjects } \\
\text { Degree of freedom } \\
\text { Not significant }\end{array}$ \\
\hline & & & $\begin{array}{l}* * \\
* * *\end{array}$ & $\begin{array}{ll}= & \text { Significant at } \mathrm{P}<0.01 \\
= & \text { Sianificant at } \mathrm{P}<0.001\end{array}$ \\
\hline
\end{tabular}

The mean $( \pm S D)$ fasting blood glucose were $5.44 \pm 0.80,5.64 \pm 1.06$ and $5.40 \pm 0.77 \mathrm{mmol} / \mathrm{l}$ in groups $A, B_{1}$ and $B_{2}$ respectively. In this study, this values were almost similar in all groups and no statistical significant difference were observed among the groups.( Table-III)

The mean $( \pm S D)$ blood Glucose $2 \mathrm{HABF}$ were $6.95 \pm 0.85,7.15 \pm 1.63,7.41 \pm 0.90 \mathrm{mmol} / \mathrm{l}$ in groups $A, B_{1}$ and $B_{2}$ respectively. The mean $(\underline{+S D})$ blood glucose $2 \mathrm{HABF}$ was significantly higher in group $\mathrm{B}_{2}$ than that of control group $A$. 
Whereas, this value were almost similar in group $B_{1}$ and $B_{2}$ and the difference was not statistically significant. (TableIII)

Table-III

Fasting blood glucose and blood glucose $2 \mathrm{HABF}$ in different groups

\begin{tabular}{|c|c|c|c|}
\hline Groups & $\bar{n}$ & $\begin{array}{c}\text { FBG }(\mathbf{m m o l} / \mathrm{L}) \\
\text { Mean } \pm \text { SD }\end{array}$ & $\begin{array}{l}\text { Blood glucose 2HABF } \\
(\mathrm{mmol} / \mathrm{L}) \text { Mean } \pm \text { SD }\end{array}$ \\
\hline $\begin{array}{l}\mathrm{A} \\
\mathrm{B}_{1} \\
\mathrm{~B}_{2}\end{array}$ & $\begin{array}{l}50 \\
50 \\
50\end{array}$ & $\begin{array}{l}5.44 \pm 0.80 \\
5.64 \pm 1.06 \\
5.40 \pm 0.77 \\
\end{array}$ & $\begin{array}{l}6.95 \pm 0.85 \\
7.15 \pm 1.63 \\
7.41 \pm 0.90 \\
\end{array}$ \\
\hline \multicolumn{4}{|c|}{ Statistical analysis } \\
\hline \multicolumn{2}{|c|}{ Groups } & $\begin{array}{c}\text { FBG } \\
\text { ( } p \text { value) }\end{array}$ & $\begin{array}{c}\text { Blood glucose 2HABF } \\
\text { (P Value) }\end{array}$ \\
\hline \multicolumn{2}{|c|}{$\begin{array}{l}A \text { vs } B_{1} \\
A \text { vs } B_{2} \\
B_{1} \text { vs } B_{2}\end{array}$} & $\begin{array}{l}0.289^{\text {ns }} \\
0.808^{\text {ns }} \\
0.201^{\text {ns }}\end{array}$ & $\begin{array}{l}0.439^{\mathrm{ns}} \\
0.010^{*} \\
0.331^{\mathrm{ns}}\end{array}$ \\
\hline
\end{tabular}

The results are expressed as Mean \pm SD. Unpaired Student's't' test was performed to compare between groups. The test of significance was calculated and $p$ values $<0.05$ was accepted as level of significance.

\begin{tabular}{|c|c|c|c|}
\hline $\begin{array}{l}\text { Group } A \text { : } \\
\text { Group } B_{1} \text { : } \\
\text { Group } B_{2} \text { : }\end{array}$ & $\begin{array}{l}\text { Fertile women } \\
\text { Primary infertility } \\
\text { Secondary infertility }\end{array}$ & $\begin{array}{l}\mathrm{n} \\
\mathrm{df} \\
\mathrm{ns}\end{array}$ & $\begin{array}{l}=\text { Number of subjects } \\
=\text { Degree of freedom } \\
=\text { Not significant }\end{array}$ \\
\hline & & $* *$ & $=\quad$ Significant at $\mathrm{P}<0.01$ \\
\hline
\end{tabular}

The mean $( \pm S D)$ serum FSH level were $6.48 \pm 3.83,3.73 \pm 2.03$ and $4.66 \pm 2.23$ IU/I in groups $A, B_{1}$ and $B_{2}$ respectively. In this study, the mean $( \pm S D)$ serum FSH levels were significantly $(P<.0001)$ lower in group $B_{1}$ and $B_{2}$ in comparison to those of control group $A$. Again, serum FSH level was lower in group $B_{1}$ than that of group $B_{2}$ but the difference was also statistically significant. (Table-IV)

The mean $( \pm S D)$ value of serum LH levels were $8.37 \pm 5.16,4.86 \pm 3.15$ and $3.47 \pm 2.03$ IU/I in groups $A, B_{1}$ and $B_{2}$ respectively. The mean $( \pm S D)$ serum LH level was significantly $(P<0.0001)$ lower in group $B_{1}$ and $B_{2}$ in comparison to those of group A. Again, this value was also significantly lower in group $B_{2}$ than that of group $B$. (Table-IV)

Table-IV

Serum FSH and LH levels in different groups

\begin{tabular}{|c|c|c|c|}
\hline Groups & $n$ & Serum FSH (IU/L) Mean \pm SD & $\begin{array}{c}\text { Serum LH (IU/L) } \\
\text { Mean } \pm \text { SD }\end{array}$ \\
\hline $\begin{array}{l}\mathrm{A} \\
\mathrm{B}_{1} \\
\mathrm{~B}_{2} \\
\end{array}$ & $\begin{array}{l}50 \\
50 \\
50 \\
\end{array}$ & $\begin{array}{l}6.48 \pm 3.83 \\
3.73 \pm 2.03 \\
4.66 \pm 2.23 \\
\end{array}$ & $\begin{array}{r}8.37 \pm 5.16 \\
4.86 \pm 3.15 \\
3.47 \pm 2.03 \\
\end{array}$ \\
\hline \multicolumn{4}{|c|}{ Statistical analysis } \\
\hline \multicolumn{2}{|c|}{ Groups } & $\begin{array}{c}\text { Serum FSH } \\
\text { (p value) }\end{array}$ & $\begin{array}{l}\text { Serum LH } \\
\text { (P Value) }\end{array}$ \\
\hline \multicolumn{2}{|c|}{$\begin{array}{l}A \text { vs } B_{1} \\
A \text { vs } B_{2} \\
B_{1} \text { vs } B_{2}\end{array}$} & $\begin{array}{c}0.0001^{* * *} \\
0.005^{* *} \\
0.032^{*}\end{array}$ & $\begin{array}{c}0.0001^{* * *} \\
0.0001^{* * *} \\
0.011^{*}\end{array}$ \\
\hline
\end{tabular}

The results are expressed as Mean \pm SD. Unpaired Student's 't' test was performed to compare between groups. The test of significance was calculated and $p$ values $<0.05$ was accepted as level of significance.

$\begin{array}{llll}\text { Group A : } & \text { Fertile women } & \mathrm{n} & =\text { Number of subjects } \\ \text { Group } \mathbf{B}_{\mathbf{1}}: & \text { Primary infertility } & \mathrm{df} & =\text { Degree of freedom } \\ \text { Group } \mathbf{B}_{2}: & \text { Secondary infertility } & * & =\text { Significant at } \mathrm{P}<0.05 \\ & & * * & =\text { Significant at } \mathrm{P}<0.01 \\ & & & * * * \quad=\text { Significant at }\end{array}$


Pearson's correlation coefficient $(r)$ was performed to observe the relationship of serum prolactin and Fasting serum insulin with different study parameter in different group. Relationship of Fasting serum insulin with FBG, serum FSH and LH in different group

\section{Correlation of fasting serum insulin with fasting serum blood glucose:}

The fasting serum insulin level showed non significant positive correlation with fasting serum glucose in group $A$ ( $r=$ $+0.141)$ and $B_{1}(r=+0.147)$. In group $B_{2}$, fasting serum insulin was positively correlated $(r=+0.356)$ with fasting serum glucose which was statistically significant.

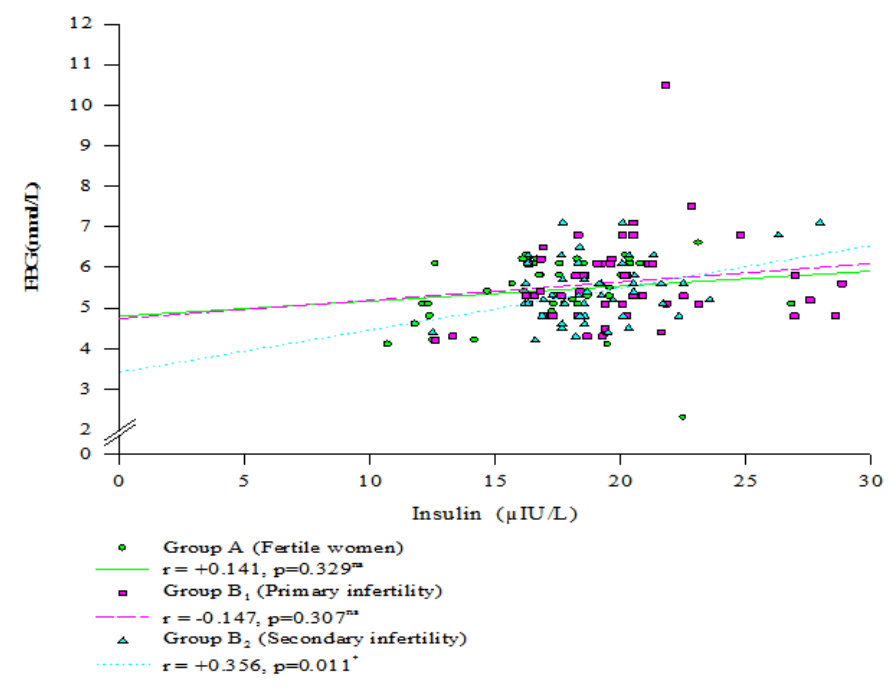

Fig-1: Correlation between serum insulin and FBG in different groups

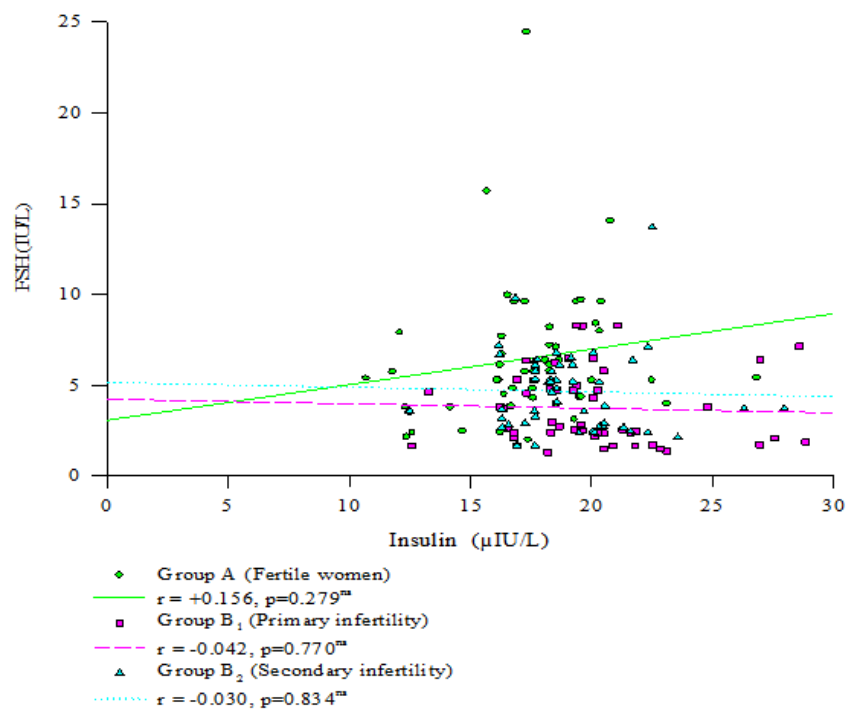

Fig 2 : Correlation of fasting serum insulin with serum FSH 


\section{Correlation of fasting serum Insulin with serum FSH}

The fasting serum insulin levels showed negatively correlated with serum FSH in group $B_{1}(r=-0.042)$ and $B_{2}(r=-$ 0.030 ) which were statistically not significant but positive correlation with serum FSH in group $A(r=+0.156)$ which was also statistically not significant. (Fig- 2)

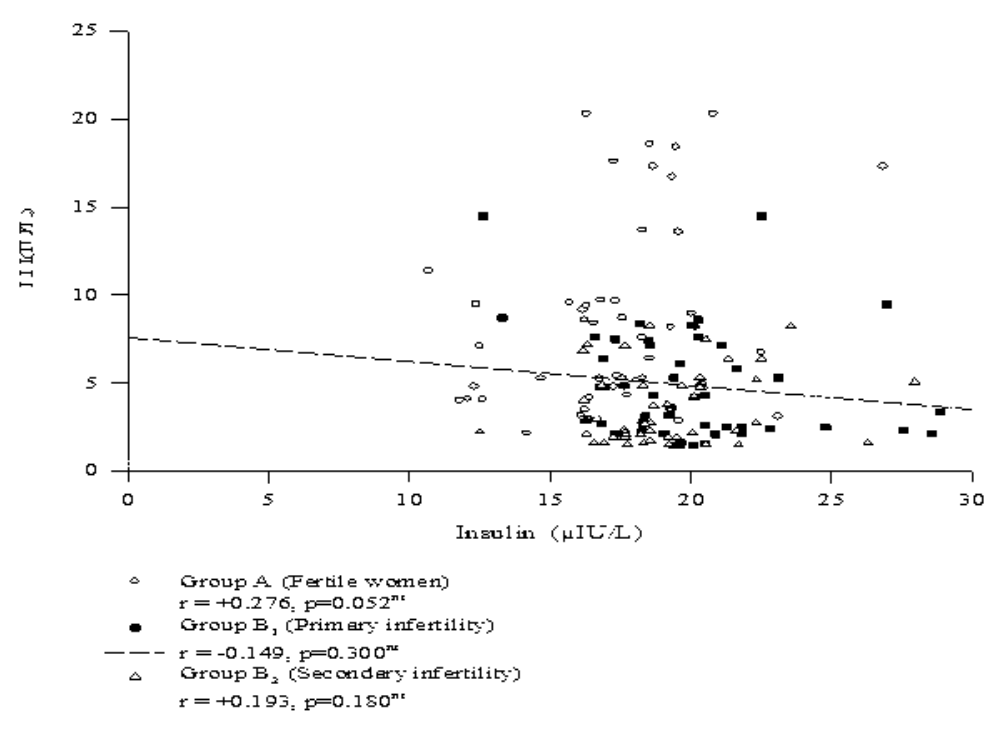

Fig 3 : Correlation of fasting serum insulin with serum LH

\section{Correlation of fasting serum insulin with serum LH}

In this study, the fasting serum insulin level showed negatively correlated with serum LH insulin in group $B_{I}$ which was statistically not significant. But positive correlation with serum $\mathrm{LH}$ in group $\mathrm{A}(r=+0.276)$ and $\mathrm{B}_{2} \quad(r=+$ 0.193) which were also statistically not significant (Fig-3).

\section{DISCUSSION}

In this study, the mean serum fasting insulin level was significantly higher $(p<0.05 \%)$ in infertile women than that of control fertile women. This finding is in agreement with that of some other researchers. ${ }^{15-19}$ Again, serum fasting insulin was higher in primary infertile women than that of secondary infertile women which was statistically not significant. Many researchers of different countries observed positive correlation between serum fasting insulin and infertility. ${ }^{15-19}$

Serum fasting insulin level was non significant positively correlated with FSH in fertile women but non significant negative correlation in both primary secondary infertile women. These observations are in consis+? nt with those of other research workers of different countries. Again, serum fasting insulin level was positively correlated with $\mathrm{LH}$ in fertile women and secondary infertile women but negatively correlated in primary infertile women. All these values were statistically not significant. Similar findings were also made by other investigators. ${ }^{9-12}$

Moreover the mean serum FSH and $\mathrm{LH}$ were significantly lower in infertile women than that of control fertile women are similar to the finding made by other research workers of different countries. However, serum FSH was significantly lower in primary infertile women than those of secondary infertile women. On the other hand, serum LH was significantly lower in secondary infertile women than that of primary infertile women. Similar observation was made by other research workers. $^{9-18}$

In this study, the mean fasting blood sugar was almost similar in infertile women and fertile women. No statistically significant differences were observed among them. Again, the mean blood glucose 2HABF were significantly higher in infertile women than that of fertile women. This finding is in agreement with those of other investigator. ${ }^{9-18}$ Some investegators reported that high level of insulin may causes excess hepatic glucose production, which reflect hepatic hepatic insulin resistance. Hyperinsulinemia in nomoglycemic adults are risk factor for developing dysglycemia (impaired fasting blood glucose, glucose tolarence or type -2 diabaties).

Many investigators of different countries reported that high level of insulin may cause increase secretion of androgens (male hormones) in the female which worsen 
the symptom of infertility. In addition, hyperinsulinemia produces the hyperandrogenism by increasing ovarian androgen production, particularly testosterone and by decreasing the serum sex hormone binding globulin concentration. The high levels of androgenic hormones interfere with the pituitary ovarian axis, leading to increased LH levels, an ovulation, amenorrhea, recurrent pregnancy loss and infertility. ${ }^{9-18}$

Some investigators suggested that hyperinsulinemia inhibites hepatic synthesis of SHBG which may causes infertility. Decrease level of SHBG may causes increases testosterone and estrogen level. Increased estrogen section causes increased $\mathrm{LH}$ and decreased FSH level. Suboptimal FSH action leads to follicular stimulation but no maturation or ovulation. As a result numerous small and immature follicles undergo atresia and also prevents normal follicular growth and causes premature follicular atresia which leads to anovulatory cycle and infertility ${ }^{9-18}$.

\section{CONCLUSION}

From the present study, it may be concluded that infertile women had significantly higher fasting serum insulin level than that of healthy fertile women. High level of insulin may have some role in decreasing serum FSH and LH which may be due to increase secretion of androgen from ovarian theca cell resulting anovulatory infertility.

\section{ACKNOWLEDGEMENT}

Authors of this study are thankful to the authority of department of Gynecology and obstetrics, infertile unite of Bangabandhu Sheik Mujib Medical University (BSMMU) for their nice cooperation during sample collection. We would also grateful to Dr. Sanwar Hossain, Director Centre for Nuclear Medicine and Ultrasound, Dhaka Medical College Campus, Dhaka for his sincere co-operation allowing me for biochemical analysis of blood sample. And finally authors are very much thankful to all the study subjects who have actively participated.

\section{REFERENCES}

1. Jeffcoate's, Pratap, K, Narendra, M. Jeffcoate's Principles of Gynecology, 7th ed, Kasturba Medical college, Manipal, Karnataka, India, 2006; 699-731.

2. FrancisS. G, David GG. Female reproductive endocrinology and infertility. Basic and clinical endocrinology, Seventh edition. University of California, Francisco, 1938; 526-527.

3. Aruna N, Pooja D, Pikee S. 'Insulin sensitizing Agents and infertility', Department obstetric and gynecology, Lady Hardeinge Medical College; New Delhi, India, 2010; 1(2): 106110 .

5. Kumar D. Prevalence of female infertility and its socioeceonomic factors in Tribal communities of central India'. Banaras Hindu University, Regional Medial Research Centre for Tribals (ICMR), Jabalpur M P, India; 2007.
6.

Garruti G, Depalo R, Vita MG, Lorusso F, Giampetruzzi F, Damato $A B$, Giorino $F$. Adipose tissue, metabolic syndrome and polycystic ovary syndrome: from pathophysiology to treatment. Reprod Biomed online 2009; 19: 552-563.

7. Consensus Development Conference on insulin Resistance. 5-6 November 1997. American Diabetes Association. Diabetes Care 1998; 21: 310-314.

8. Michael $\mathrm{L}$, Traub. Assessing and treating resistance in women with polycystic ovarian syndrome, Department of obstetrices and gynecology, staten island university hospita, USA, 2011; 2(3): 33-40.

9. Azziz R, Carmina E, Dewailly D, Diamanti KE. Escobar MHF, Futterweit W, Janssen $O E$, Legro RS, Norman RJ, Taylor $A E$, Witchel SF. Task Force on the Phenotype of the Polycystic Ovary Syndrome of The Androgen Excess and PCOS Society. The Androgen Excess and PCOS Society criteria for the polycystic ovary syndrome: the complete task force report. Fertile Steril 2009; 9 456-488, doi:10.1016. fertnstert, pp, 906,no. 035. [Pub Med][Cross Ref].

10. Sakumoto $T$, Tokunaga $Y$, Tanaka $H$, Nohara $M$, Nakaza A, Higashi $M$. Insulin resistance or hyperinsulinemia and reproductive disorder in infertile women, 'depertment of Infertility and Endocrinology, Tomishior Central Hospital, Okinawa, Tomish, Japan, 2010; 9(4): 185-190.

11. Dale PO, Tanbo T, Vaaler S. Body weight hyperinsulinemia and gonadotropin levels in the polycystic ovarian syndrome evidence of two district populations'. Fertil. Steril. 1992; 58: 487-491.

12. Dale PO, Tanbo T, Djoseland O. Persistence of hyperinsulinemia in polysyctic ovarian syndrome after ovarian supperession by Gn RH-agoinst. Acta Endocrinol. Scand (Copenh.) 1992; 132136

13. Bareieri RL, Makris A, Randall RW. Insulin stimulates androgen accumulation in incubations of ovarian stoma obtained from women with hyperandrogenism. J Clin Endrocinol 1986; 904910.

14. Nestler JE, Clore JN, Blackard WG. The central role of obesity (hyperinsulinemia) in the pathogenesis of the polycysic ovary syndrome. Am J Obst Gynecol 1989; 161: 1095-1097.

15. Apridonidze T, Essah PA, Iuorno MJ, Nestler JE. Prevalence and characteristics of metaboilic syndrome in women with polycystic ovary syndrome. J Clin Endrocrinol Metab 2004; 90: 1929-1935, doi;10,1210/jc. 1045 [Pub Med].

16. BhathenaRK, Insulin resistance and the long-term consequence of polycysticovarysyndrome. J Obs Gynae, Mumbai, India, 2010; 2: 105-110.

17. Ehrmann DA. Polycystic ovary syndrome. N Engl J Med 2005; 352: 1223-36.

18. Farrell K, Antoni MH. Insulin rsistance, obesity, inflammation, and depression in polycystic ovary syndrome: biobehavioral mechanisms and interventions. Fertil Steril. 2010; 94: 15651574.

19. Freeman R, Pollack R, Rosenbloom, E. Assessing impaired glucose tolerance and insulin resistance in polycystic ovarian syndrome with a muffin test: Alternative to glucose tolerance test Endocr Pract 2010; vol. 24.

Guyton AC, Hall J. Textbook of Medical Physiology, $11^{\text {th }}$ ed, SB Saunders, Singapore; 2006.

Ganong WF. Review of Medical Physiology, $23^{\text {rd }}$ ed, McGraw-Hill Companies, New York; 2005.

20. Haq F, Aftab O, Rizvi J. Clinical, biochemical and ultrasonographic features of infertile women with polycystic ovarian syndrome,' department of Obstetrics and Gynecology, Aga Khan University Hospital, Karachi, Pakistan, 2007; 2(17): 76-80. 
21. Irfan Y, Mert K, Adil C, Engin G, Gurhan K, Zahit B. Polycystic Ovary Syndrom and Prolactinoma Association', Division of Hematology, Adnan Medical Faculty, Aydin, Turkey. Inter Med 2009; 48: 611-613.

22. Legro RS, Castracane VD, Kauffman RP. Detecting insulin resistance in polycystic ovary syndrome: purposes and pitfalls". Obstet Gynecol Surv 2004; 59: 141-54.

23. Leon, S, Marc FA, FA Philadelphia: Lippincott Williams and Wilkins, Amenorrhoea in clinical gynecologic endocrinologic and infertility; 2005: 429.

24. Moran L, Teede $H$. Metabolic features of the reproductive phenotypes of polycystic ovary syndrome'. Hum Reprod Update 2009; 15: 477-488.

25. Padmanabhan V, Veiga-Lopez A, Abbott DH, Recabarren SE Herkimer C. Development programming: impact of prenatal testosterone excess and postnatal weight gain on insulin sensitivity index and transfer of traits to offspring of overweight females'. Endocrinology 2002; 151: 595-605.

26. Strowizki T, Capp E, von Eye Corleta H. The degree of cycle irregularity correlates with the grade of endocrine and metabolic disorders in PCOS patients. Eur J Obstet Gynecol Reprod Biol. 2010; 149: 178-181.

27. Teede H, Deeks A, Moran L. Polycistic ovary syndrome, a complex condition with psychological, reproductive and metabolic manifestations that impacts on health across the lifespan,' Jean Hailes Clinica research unit, Australia 2002; 10(1186/1741): 7015-41.

28. Williams C, Giannopoulos T, Sherriff EA. Investigation of infertility with the emphasis on laboratory testing and with reference to radiological imaging. J Clin Pathol 2003; 56: 261-7. 